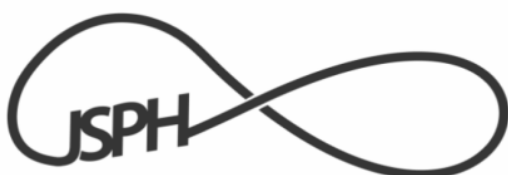

P-ISSN : 2502-7875 E-ISSN : 2527-5879

\title{
PERGESERAN MAKNA RITUAL IBADAH DI ERA DIGITAL
}

\section{Udji Asiyah ${ }^{1}$, Ratna Azis Prasetyo, Sudjak}

Program Studi Sosiologi Fakultas Ilmu Sosial dan Ilmu Politik Universitas Airlangga

Program Studi Dirosah Islamiyah Fakultas Adab UIN Sunan Ampel

${ }^{1}$ Email : udji.asiyah@ fisip.unair.ac.id

\begin{abstract}
Abstrak
Hadirnya Smartphone menjadi alasan terjadinya pergeseran makna dalam ritual ibadah mengapa saat ini dan dulu berbeda, tempat-tempat yang mestinya sacral terkesan menjadi tempat wisata baru, banyak orang berselfie ria di depannya kemudian diupload dimedia sosial, pemandangan seperti ini tidak ditemui pada masa silam. Penulisan artikel ini bertujuan untuk menjelaskan pergeseran makna ritual ibadah yang semestinya dapat dinikmati namun bergeser lebih mengedepankan kesibukan mencari sudut pandang yang bagus sebagai background untuk berfoto atau merekam video dengan tidak mempedulikan kekhusukan beribadah serta keselamatan jamaah yang lain.Study ini dilakukan secara kualitatif, data diperoleh melalui observasi dan wawancara, hasil penelitian ini menemukan bahwa kesalehan secara social lebih mampu mengeliminir pemanfaatan alat teknologi dalam melakukan ibadah dibanding kesalehan secara ritual yang cederung lebih mengeksplor peralatan teknologi.
\end{abstract}

Kata kunci : kesalehan sosial, kesalehan ritual, media sosial, sakral, profan

\section{THE SHIFTING MEANING OF WORSHIP RITUAL IN THE DIGITAL ERA}

\begin{abstract}
The presence of Smartphones is the reason for the shifting of meaning in rituals of worship why today and first are different, places that should be sacred seem to be new tourist attractions, many people have selfies in front of them then uploaded in social media, scenes like this were not found in the past. The writing of this article aims to explain the shift in the meaning of worship rituals that should be enjoyed but shift to prioritizing busyness looking for a good perspective as a background for taking pictures or recording videos with no regard for the special worship and safety of other worshipers. This study was conducted qualitatively, data obtained through observation and interviews, the results of this study found that social piety is better able to eliminate the use of technological tools in worship than ritual piety which tends to explore technological equipment.
\end{abstract}

Keywords : social piety, ritual piety, social media, sacred, profane 


\section{PENDAHULUAN}

Desakralisasi nilai agama, menjadikan ego beragama tidak memberikan arti bagi pemeluknya (dangkal dan hampa makna) tidak terasakan menimpa generasi digital ini. Seperti halnya ritual ibadah umroh yang dimulai dengan ihram, berniat untuk memulai umrah, thawaf, sa'i, tahallul dan dilakukan secara tertib, ini merupakan suatu yang sakral baik tempat, waktu maupun tatacaranya, meskipun ibadah umrah merupakan ibadah yang bersifat pribadi dan manfaatnya kembali kepada diri seseorang yang melaksanakanya. Karena dilakukan bersamaan dengan orang banyak tentunya juga berkaitan dengan kepentingan orang banyak juga.

Dalam kaidah fiqh Imam Suyuti dalam Wahab (2015) menyatakan bahwa: "ibadah yang utama adalah ibadah yang bermanfaat bagi orang lain dibandingkan dengan ibadah yang hanya bermanfaat bagi diri sendiri". Dalam konteks ini ketika melakukan ritual ibadah umroh yang dilakukan secara kolektif (umum) dengan memperhatikan kepentingan orang lain yang juga sama-sama melakukannya niscaya akan lebih baik dibanding hanya memperhatikan kepentingan individunya sendiri dalam melaksanakannya. Sistem ritus (ibadah) lahir dari kepercayaan dan penghayatan manusia kepada penciptanya, Harun Nasution dalam Dermawan (2002) menyatakan ibadah dalam arti luas bukanlah sekedar beribadah kepada Tuhan, tetapi tentang bagaimana nilai-nilai yang ada didalam ibadah tersebut memberikan implikasi nilai pada kehidupan sosial.

Ibadah yang berimplikasi pada nilai-nilai sosial seringkali ditengarahi sebagai bentuk suatu kesalehan sosial. Demikian pula dalam melaksanakan ritual ibadah umroh sudah semestinya penuh toleransi sehingga tidak terjadi adanya perselisihan, ketidaksabaran, ketidakpedulian, saling dorong berebut mencium hajar aswad, mengganggu kekhusukan orang lain, membahayakan orang lain dan lain sebagainya. Apalagi dalam ritual ibadah umroh, terkait dengan ruang dan tempat suci yaitu Ka'bah (Masjidil Haram, Makkah). Dalam keyakinan Muslim bahwa Ka'bah merupakan tempat suci dan disucikan (sakral) dan bagi umat islam merupakan kiblat dalam shalat serta tempat tawaf (mengelilingi) bagi yang sedang berkunjung untuk berziarah. L.Pass (2001) mengatakan Ka'bah memiliki nilai kesakralan karena merupakan objek yang suci dan menakjubkan.

Mircea (2002) mengatakan bahwa manusia di era modern saat ini memiliki kecenderungan menganggap bahwa semua ruang adalah sama. Hal tersebut menyebabkan terjadinya kemiskinan religius karena anggapan kesamaan ruang di era masyarakat modern telah menyebabkan hilangnya dimensi penting dalam beragama. Oleh sebab itu, dalam melakukan riset tentang agama, sangat penting melihat perspektif orang yang beriman, kepercayaan mereka untuk menjalani agamanya karena ruang sakral hanya bisa dirasakan oleh orang-orang yang beriman.

Berkenaan kesalehan ritual biasanya terukur berdasarkan seberapa taat seseorang menjalankan rukun Islam (sholat, zakat, puasa, haji), sedangkan kesalehan sosial merupakan bentuk kesalehan yang berkaitan dengan dimensi sosial (kegiatan sosial, toleransi, tingkat kepeduliaannya terhadap sesamanya, cinta kasih, saling menghargai dan lain sebagainya.

Banyak studi yang telah dilakukan tentang kesalehan sosial yaitu (Ibrahim, 2002; Riesebrodt,1993; Jati， 2015; Riadi， 2014; Wahab, 2015), tetapi studi tentang makna ritual ibadah yang dikaitkan dengan era digital belum nampak. Studi ini mengkaji tentang bagaimana pergeseran makna ritual ibadah di era digital yang berpengaruh terhadap kesalehan sosial, daya pendorong terjadinya pergeseran serta bentuk pergeseran yang terjadi.

\section{METODE PENELITIAN}

Penelitian ini menggunakan metode kualitatif. Menurut Max Weber, metode verstehen merupakan upaya untuk memahami makna dibalik tindakan sosial tertentu dalam hal ini makna dibalik tindakan yang terkandung didalam ibadah umroh. Melalui metode ini, penelitian tidak hanya melihat gejala yang kasat mata, tetapi juga mempertimbangkan sudut pandang pelakunya. Sehingga penelitian ini 
tidak menekankan pada kuantitas data, tetapi lebih pada kedalaman atau kualitas data dengan format deskriptif yaitu bertujuan untuk menggambarkan berbagai kondisi, situasi, realitas sosial yang ada di masyarakat.

Data dalam studi ini, selain studi kepustakaan juga dilakukan dengan wawancara beberapa informan yang terlibat dalam pelaksanaan umroh dan pembimbingnya secara purposive diperoleh sebanyak 9 orang informan. Penelitian yang bermaksud untuk mengkaji bagaimana pergeseran makna ritual ibadah umroh di era digital, daya pendorong terjadinya pergeseran serta bentuk pergeseran yang terjadi. Peneliti melakukan wawancara mendalam (indepth interview) pada informan untuk menggali data melengkapi data yang belum diperoleh dengan wawancara terstruktur (kuesioner). Selain itu, peneliti melakukan partisipasi observatif dalam pelaksanaan ritual ibadah umroh tersebut karena peneliti ikut terlibat dalam pelaksanaan tersebut.

Analisis data dilakukan pada semua data yang berhasil dikumpulkan, baik primer maupun sekunder, selanjutkan diklasifikasi dan peneliti membuat interpretasi dengan memberikan arti sesuai dengan tema atau permasalahan yang dikaji. (Lihat gambar 1)

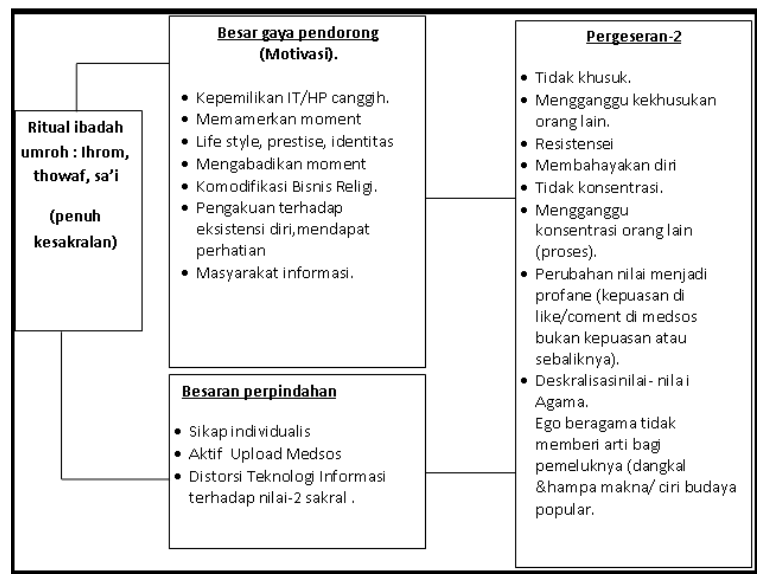

\section{Gambar 1. Kerangka Berpikir Pergeseran Makna Ritual Ibadah di era Digital}

\section{HASIL DAN PEMBAHASAN} Makna Ritual Ibadah Umrah

Hasil wawancara menunjukkan variasi jawaban informantentang ritual ibadah umroh namun antara informan satu dengan lainnya saling menguatkan tentang makna ritual ibadah umroh yang mereka lakukan. Substansi yang mereka ungkapkan dalam ibadah umroh tidak banyak perbedaan antara satu sama lain yaitu mengarah kepada satu makna yaitu bahwa hakekat ritual ibadah umroh adalah semata-mata untuk beribadah mencari keridhoanNya dengan semua aktivitas yang harus dilakukan yakni berbasis spirit semata-mata murni karena ingin lebih dekat kepada Allah SWT agar iman menjadi lebih kuat, baik dari informan yang sudah melakukan haji maupun yang belum melaksanakan haji.

Namun data menunjukkan bahwa orientasi tindakan masyarakat terhadap ritual ibadah umroh ada beberapa perbedaan orientasi sebagaimana konsep Max Weber dalam Siahaan (1986) bahwa untuk menyelidiki tindakan individu beserta alasannya yang subyektif. Weber memakai pendekatan verstehen yakni suatu pendekatan yang berusaha memahami makna yang menjadi dasar dan mengitari peristiwa sosial beserta historisnya. Weber membagi tindakan sosial menjadi empat antara lain : Pertama, rasional instrumental (zwerck rational), adalah tindakan sosial manusia yang dalam menanggapi lingkungan eksternalnya menggunakan pertimbangan rasional. Kedua, rasional orientasi nilai (wert rational), merupakan tindakan sosial yang rasional, namun yang menyandarkan diri kepada suatu nilai-nilai absolute tertentu (orientasi nilai). Nilai-nilai yang dijadikan sandaran ini bisa nilai etis, estetis, keagamaan, atau juga nilai-nilai yang lain. Jadi di dalam tindakan berupa wert rational ini manusia selalu menyandarkan tindakannya yang rasional pada suatu keyakinan terhadap suatu nilai tertentu. Ketiga affectual, yaitu tindakan sosial yang muncul karena adanya dorongan atau motivasi yang bersifat emosional. Rasa cinta, kasihan maupun luapan kemarahan merupakan tindakan affectual. 
Keempat, tradisional, adalah tindakan sosial yang didorong dan berorientasi pada tradisi masa silam. Tradisi dalam pengertian ini merupakan suatu kebiasaan bertindak yang berkembang di masa silam. Mekanisme tindakan ini selalu berlandaskan hukum normatif yang telah ditetapkan oleh masyarakat, tanpa perhitungan secara matang, melainkan lebih karena kebiasaan yang berlaku selama ini dalam masyarakat. Itulah sebabnya, tujuan dan cara dari tindakan ini cara dari tindakan ini cenderung tidak direncanakan, karena pada dasarnya tindakan tersebut sudah pernah dilakukan dan diulang-ulang. Tindakan-tindakan sosial tersebut menurut Weber berpengaruh terhadap pola hubungan sosial di masyarakat serta mempengaruhi struktur sosial masyarakat.

\begin{tabular}{|c|c|c|c|c|}
\hline \multirow[b]{2}{*}{ Katagorisasi } & \multicolumn{4}{|c|}{ Makna Tindakan } \\
\hline & $\begin{array}{c}\text { Makna } \\
\text { tentang } \\
\text { ritual } \\
\text { ibadah } \\
\text { umroh }\end{array}$ & $\begin{array}{c}\text { Tinda } \\
\text { kan } \\
\text { yang } \\
\text { dilaku } \\
\text { kan }\end{array}$ & Alasan & $\begin{array}{l}\text { Orientasi } \\
\text { Tindakan }\end{array}$ \\
\hline Pertama & $\begin{array}{l}\text { Ibadah } \\
\text { hanya } \\
\text { karena } \\
\text { Allah }\end{array}$ & $\begin{array}{l}\text { Jika } \\
\text { biaya } \\
\text { sudah } \\
\text { terkum } \\
\text { pul } \\
\text { melaku } \\
\text { kan } \\
\text { ibadah } \\
\text { umroh }\end{array}$ & $\begin{array}{l}\text { Beriba } \\
\text { dah } \\
\text { sekalig } \\
\text { us } \\
\text { dapat } \\
\text { wisatan } \\
\text { ya } \\
\text { untuk } \\
\text { menda } \\
\text { patkan } \\
\text { kebaha } \\
\text { giaan } \\
\text { lahir } \\
\text { dan } \\
\text { batin. }\end{array}$ & $\begin{array}{l}\text { Rasional } \\
\text { instrumen } \\
\text { (zwerck } \\
\text { rational) }\end{array}$ \\
\hline Kedua & $\begin{array}{l}\text { Ibadah } \\
\text { hanya } \\
\text { karena } \\
\text { Allah }\end{array}$ & $\begin{array}{l}\text { Berusa } \\
\text { ha } \\
\text { keras } \\
\text { untuk } \\
\text { bisa } \\
\text { melaku } \\
\text { kan } \\
\text { ibadah } \\
\text { umroh }\end{array}$ & $\begin{array}{l}\text { Agar } \\
\text { dapat } \\
\text { masuk } \\
\text { surga }\end{array}$ & $\begin{array}{l}\text { Tindakan } \\
\text { tradisional }\end{array}$ \\
\hline Ketiga & $\begin{array}{l}\text { Ibadah } \\
\text { hanya } \\
\text { karena } \\
\text { Allah }\end{array}$ & $\begin{array}{l}\text { Menab } \\
\text { ung } \\
\text { untuk } \\
\text { bisa } \\
\text { melaks } \\
\text { anakan } \\
\text { ibadah } \\
\text { umroh }\end{array}$ & $\begin{array}{l}\text { tanda } \\
\text { syukur } \\
\text { kepada } \\
\text { Allah } \\
\text { atas } \\
\text { kesehat } \\
\text { an dan } \\
\text { rizki } \\
\text { yang } \\
\text { telah } \\
\text { diberik } \\
\text { an oleh } \\
\text { Allah }\end{array}$ & $\begin{array}{l}\text { Rasional } \\
\text { orientasi } \\
\text { nilai (wert } \\
\text { rational) } \\
\text { (rasional } \\
\text { orientasi } \\
\text { nilai) }\end{array}$ \\
\hline
\end{tabular}

Tabel 1. Katagorisasi Orientasi Tindakan Dalam Ritual Ibadah Umroh (Sumber: data penelitian)
Studi ini menemukan bahwa walaupun para informan memberikan makna ibadah umroh dengan substansi yang sama yakni ibadah semata-mata karena Allah, namun dalam orientasi tindakannya terbedakan dalam tiga katagori orientasi yakni Pertama, rasional instrumental (zwerck rational), adalah informan yang ketika memiliki biaya terkumpul sering memilih melakukan ibadah umroh dibanding wisata dengan alasan beribadah sekaligus dapat wisatanya sehingga mendapatkan kebahagiaan lahir dan batin. Kedua, tindakan sosial yang didorong dan berorientasi kepada tradisi (suatu kebiasaan) yaitu informan berusaha keras untuk bisa melakukan ibadah umroh dengan suatu harapan kelak dapat masuk surga.Ketiga, rasional orientasi nilai (wert rational), adalah informan yang terus menabung untuk bisa melaksanakan ibadah umroh sebagai tanda syukur kepada Allah atas kesehatan dan rizki yang diberikan oleh Allah SWT. (Lihat tabel 1)

Orientasi tindakan sosial tersebut menurut Weber akan mempengaruhi pola-pola hubungan sosial serta struktur sosial masyarakat dan dalam konteks ibadah umroh hanya muncul tiga katagori yaitu rasional instrumental, rasional orientasi nilai, berorientasi kepada tradisi.

\section{Pergeseran Makna Ritual Ibadah di Era Digital}

Dewasa ini media digital memainkan peran penting lebih dominan dalam membangun hubungan-hubungan sosial baik yang konkret maupun yang sifatnya abstrak dibanding dengan hubungan-hubungan sosial di dunia nyata.

Hidup di era globalisasi mendapatkan informasi cukup mudah, dimanapun, dengan media apapun, tanpa harus bertatap muka, cukup melalui gadget seperti smartphone, laptop, komputer, tablet,dan piranti lainnya. Kegiatan komunikasi di dunia maya baik dengan internet maupun media sosial dapat menciptakan suatu masyarakat jaringan (network society). Menurut Castells (1996) menyebutkan bahwa komputer dan aliran informasi telah mengubah dunia dan menimbulkan berbagai masalah sosial-ekonomi serta budaya yang menjadi ciri masyarakat modern kontemporer (pasca industri). 
Perubahan teknologi komunikasi selain membawa dampak positif juga dampak negatif seperti adanya penurunan kepekaan masyarakat terhadap orang-orang yang ada disekitarnya, seseorang akan lebih mudah untuk menjalin komunikasi dan membangun relasi dengan mereka yang jauh melaui gadget dibanding dengan orang yang ada disekitarnya, menjadi sangat individualis dan sulit interaksi ataupun sosialisasi yang dilakukan di dunia nyata.

Menurut Priyanto (2016) mereka yang selalu terhubung dan terbiasa dengan teknologi informasi dan selalu menggunakan perangkat, serta tidak memandang umur, mereka selalu terhubung ke internet dan menggunakannya, sangat aktif dan partisipatif menjelajah dunia online baik lewat komputer maupun ponsel adalah merupakan generaci $\mathrm{C}$ atau dengan kata lain sebagai bagian kehidupan digital, dikarenakan atas respon teknologi informasi, mereka mempunyai kebutuhan untuk terkoneksi, membutuhkan untuk berkolaborasi. Generasi ini juga membuat apa yang dulu dianggap sebuah privasi dan personal sekarang menjadi terbuka dan menjadi konsumsi public bahkan dilengkapi dengan foto dan rekaman video mereka dalam tanda kutip "narsis".

Toffler dalam Kumorotomo dan Margono (1998) menjelaskan ada tiga gelombang peradaban yang dijalani umat manusia. Gelombang pertama (800 SM-1700), manusia hidup dalam peradaban agraris dan pemanfaatan energi. Gelombang kedua (1700 - 1970), ditandai dengan adanya revolusi industri. Gelombang ketiga (1970-sekarang), manusia hidup dalam peradaban yang didukung dengan kemajuan teknologi informasi, pengolahan data, penerbangan, aplikasi luar angkasa, bioteknologi dan komputer. Abad 21 disebut sebagai abad informasi yaitu informasi diproduksi oleh industri secara secara besar-besaran kemudian didistribusikan secara luas, dapat diakses dengan mudah, sehingga menjadi bagian terpenting dalam kehidupan manusia. Ketergantungan terhadap perkembangan teknologi informasi yang tinggi, membuat sebagian besar masyarakat selalu menggunakan teknologi terbarunya dengan volume yang besar.
Globalisasi telah melahirkan masyarakat yang konsumtif, kepentingan pasar cenderung lebih kuat dari sistem nilai yang ada pada institusi spiritual sehingga dapat merubah orientasi pandangan yang tidak lagi bertempu pada sistem nilai yang dianut.Tingkat konsumtifitas masyarakat sangat terlihat dalam penggunaan teknologi,mereka berbondogbondong membeli keluaran gadget terbaru yang bermunculan.

Manusia modern banyak kehilangan dimensi-dimensi penting dalam beragama, karena ruang sakral hanya dapat dirasakan oleh orang-orang yang religius (Mircea, 2002). Dalam hal ini sering kaliterjadinya pergeseran nilai dari sesuatu yang dianggap sakral berubah menjadi sesuatu yang bernilai materi atau profan, duniawi, sehingga berbagai bentuk kegiatan ritual ibadah juga selalu dihubungkan dengan hal yang bersifat material.

Studi ini menemukan bahwa pemaknaan dalam ritual ibadah umroh secara substantif cenderung tidak muncul perbedaan, namun selain memiliki orientasi tindakan yang berbeda juga ada faktor pendorong kuat yang mempengaruhinya sehingga memunculkan perilaku tindakan yang berbeda, membawa perbedaan besarnya perpindahan terhadap pergeseran-pergeseran yang terjadi dalam tindakan ritual ibadah umroh, data menunjukkan beberapa katagori pergeseran makna ritual ibadah : 1) Informan yang aktif upload medsos di setiap moment adalah mereka yang didukung oleh kepemilikan handphone canggih, Life style, prestise, identitas, terlibat dibanyak grup w.a/twitter dll (masyarakat informasi) serta merasa mendapat pengakuan terhadap eksistensi diri dan mendapat perhatian. Dari sini memunculkan perubahan nilai yang mestinya sacral menjadi profan (kepuasan di like atau coment di medsos) dan bahkan menjadikan ritual ibadah umrohnya menjadi tidak khusuk dan tidak konsentrasi. 2) Informan yang memiliki sikap individualis, terdistorsi teknologi informasi terhadap nilai sakral didukung kuat oleh kepemilikan Handphone canggih, keinginan memamerkan moment dan mengabadikan moment kondisi dan situasi serta 
ada komodifikasi bisnis religi. Dari sini memunculkan Desakralisasi nilai-nilai Agama, ego beragama tidak memberi arti bagi pemeluknya, memvideo, memfoto disaat ritual ibadah berlangsung sehingga juga berdampak dapat mengganggu kekhusukan orang lain. 3) Informan yang aktif upload medsos merasa bangga dan puas adalah mereka yang didukung kepemilikan $\mathrm{Hp}$ canggih dan mengambil foto saat ritual dan lansung share ke grup whatsapp, hal ini memunculkan pergeseran ritual ibadah yang mestinya bisa khusuk menjadi tidak khusuk dan tidak konsentrasi. 4) Informan yang terdistorsi teknologi informasi terhadap nilainilai sacral yaitu informan yang walaupun hanya didukung oleh kemilikan handphone yang belum canggih, namun ketika melihat orang didekatnya memvideo moment dan memfotonya langsung saja informan ikut berfoto padahal sedang melakukan ritual ibadah, hal ini memunculkan ritual ibadahnya tidak konsentrasi dan tidak khusuk. 5) Informan yang suka langsung share, merasa senang live sehingga segera diketahui oleh teman-temannya, mereka adalah yang didukung kuat dengan hanphone yang canggih,juga ada keinginan untuk menunjukkan eksistensi diri sehingga mengambil gambarnya pun dilakukan saat pelaksanaan ritual bahkan mereka tidak peduli ketika membahayakan diri sendiri seperti karena hampir terjatuh. 6) Informan yang hanya mengambil gambar untuk dokumentasi pribadi dan keluarga adalah mereka yang didukung dengan handphone yang canggih dan juga mengabadikan moment namun dalam mengambil gambar dilakukan setelah selesai ritual ibadah, hal tersebut memunculkan sikap resintensi dalam bentuk expressive terhadap pengexploran $\mathrm{Hp}$ ketika saat ritual berlangsung. (Lihat tabel 2)

Data tersebut menunjukkan bahwa motivasi sebagai pendorong kuat suatu pergeseran dalam ritual ibadah didominasi oleh kepemilikan smartphone yang canggih tidak diikuti oleh suatu kearifan yang mengarah pada kesalehan sosial yang selalu memperhatikan juga terhadap keselamatan orang lain atau kepedulian terhadap orang lain apalagi sama-sama dalam melaksakan umroh.

\begin{tabular}{|c|c|c|}
\hline Pendorong (Motivasi) & $\begin{array}{c}\text { Besaran } \\
\text { Perpindahan }\end{array}$ & Pergeseran \\
\hline $\begin{array}{l}\text { Kepemilikan Hp canggih } \\
\text {; Life style, prestise, } \\
\text { identitas ; banyak grup } \\
\text { whatsapp (masyarakat } \\
\text { inforrmasi). } \\
\text { Pengakuan terhadap } \\
\text { eksistensi diri, mendapat } \\
\text { perhatian }\end{array}$ & $\begin{array}{l}\text { Aktif upload } \\
\text { media sosial } \\
\text { dalam setiap } \\
\text { moment yang } \\
\text { dilakukan }\end{array}$ & $\begin{array}{l}\text { - Perubahan nilai } \\
\text { menjadi profan } \\
\text { (kepuasan di } \\
\text { like/mendapat } \\
\text { coment di } \\
\text { medsos). } \\
\text { - Tidak khusuk } \\
\text { Tidak } \\
\text { konsentrasi }\end{array}$ \\
\hline $\begin{array}{l}\text { - Kepemilikan Hp } \\
\text { canggih } \\
\text { - Memamerkan } \\
\text { moment } \\
\text { - Mengabadikan } \\
\text { moment di segala } \\
\text { posisi dan situasi } \\
\text { - Komodifikasi Bisnis } \\
\text { Religi }\end{array}$ & $\begin{array}{l}\text { - Sikap } \\
\text { individualis } \\
\text { - Distorsi } \\
\text { Teknologi } \\
\text { Informasi } \\
\text { terhadap } \\
\text { nilai-nilai } \\
\text { sakral }\end{array}$ & 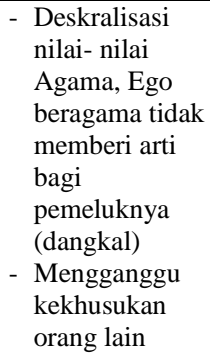 \\
\hline $\begin{array}{l}\text { - Kepemilikan } \\
\text { handphone canggih } \\
\text { - Mengambil foto saat } \\
\text { ritual dan lansung } \\
\text { share ke grup } \\
\text { whatsapp }\end{array}$ & $\begin{array}{l}\text { Upload di } \\
\text { medsos, } \\
\text { Bangga dan } \\
\text { puas }\end{array}$ & $\begin{array}{l}\text { Tidak khusuk } \\
\text { Tidak konsentrasi }\end{array}$ \\
\hline $\begin{array}{l}\text { Kepemilikan Hp tidak } \\
\text { canggih }(j a d u l) ; \text { Ketika } \\
\text { melihat orang video \& } \\
\text { foto langsung ikut action } \\
\text { padahal sedang } \\
\text { melakukan ritual. }\end{array}$ & $\begin{array}{l}\text { Distorsi } \\
\text { Teknologi } \\
\text { Informasi } \\
\text { terhadap } \\
\text { nilai-nilai } \\
\text { sakral } \\
\end{array}$ & $\begin{array}{l}\text { Tidak khusuk } \\
\text { Tidak konsentrasi }\end{array}$ \\
\hline $\begin{array}{l}\text { - Kepemilikan Hp } \\
\text { canggih } \\
\text { - Eksistensi diri } \\
\text { - - Mengambil foto } \\
\text { ketika ritual }\end{array}$ & $\begin{array}{l}\text { Langsung } \\
\text { share karena } \\
\text { senang live } \\
\text { teman-teman } \\
\text { tahu }\end{array}$ & $\begin{array}{l}\text { Membahayakan } \\
\text { diri karena } \\
\text { hampir terjatuh }\end{array}$ \\
\hline $\begin{array}{l}\text { Handphone canggih } \\
\text { Mengabadikan moment. } \\
\text { Mengambil gambar } \\
\text { setelah } \\
\text { Selesai ritual }\end{array}$ & $\begin{array}{l}\text { Hanya untuk } \\
\text { dokumentasi } \\
\text { pribadi dan } \\
\text { keluarga }\end{array}$ & $\begin{array}{l}\text { Resistensi } \\
\text { terhadap } \\
\text { pemanfaatan HP } \\
\text { ketika ritual. }\end{array}$ \\
\hline
\end{tabular}

Tabel 2. Kategorisasi Pergeseran Makna

\section{Ritual Ibadah}

\section{(Sumber: Data Penelitian)}

Sebagaimana penuturan salah seorang informan yang memiliki handphone canggih yang selalu mengabadikan moment di segala posisi dan situasi mengatakan :

Tangan saya itu gatal jika tidak mengambil gambar saat moment-moment yang bagus dan bisa saya share langsung, dengan begitu kan banyak teman-teman yang tahu keberadaan kita kita banyak dimintai doa dan kita didoakan.Kita juga harus berani mengambil posisi yang bagus dan kadang juga agak dorong-dorong dikit orang lain, kadang karena posisinya bagus kadang kita berdoa juga agak lama dikit deeh, yang lain mohon tunggu bentar kan gak papa. 
Bisa diketahui bahwa dukungan kuat adanya teknologi yang canggih, mempengaruhi seseorang menjadi individualis meskipun sedang dalam melaksanakan ritual ibadah, walaupun kesalehan ritual dimiliki namun tidak diimbangi dengan kesalehan sosial niscaya akan membawa ritual ibadahnya menjadi dangkal.

\section{PENUTUP}

Studi ini menyimpulkan dengan beberapa proposisi yaitu walaupun makna ritual ibadah umroh tidak berubah, Namun dengan smartpone ditangan membawa perubahan perilaku sesuai dengan orientasi tindakan sosialnya dan mempengaruhi implikasi atau pelaksanaan ritual ibadah tersebut.

Kesalehan secara sosial (sikap toleransi dan peduli terhadap jamaah lain yang samasama melaksanakan ibadah) lebih mampu meminimalisir pemanfaatan alat teknologi dalam melakukan ritual ibadah sehingga makna ibadah sebagai ritual yang sakral tetap terjaga. Sedangkan jamaah yang hanya memiliki kesalehan secara ritual (ibadah individual) saja cenderung lebih mengeksplor peralatan teknologi untuk menampilkan kegiatan ritual ibadahnya tanpa memperdulikan bahwa apa yang sedang dilakukan dapat mengganggu ritual jamaah lain, identitas sebagai seorang religius di sosial media, sehingga esensi ibadah menjadi sebatas kesenangan duniawi.

Pelaksanaan ibadah ritual yang terdistorsi teknologi informasi menjadikan nilai-nilai sacral dalam ritual ibadah menjadi profan serta mendapatkan kepuasan ego duniawi.

\section{DAFTAR RUJUKAN}

Castells, M. (1996). The Rise of The Network Society (The Information Age: Economy, Society, and Culture). London:Willey-Blackwell

Dermawan, A, dkk., (ed.). (2002). Metodologi Ilmu Dakwah. Yogyakarta:LSFI.

Ibrahim, I. (2002). Dunia Simbolik dan Gaya Hidup dalam Beragama. Mediator, $3(1): 26-28$.
Jati, W.R. (2015). Kesalehan Sosial Sebagai Ritual Kelas Menengah Muslim. Ibda Jurnal Kebudayaan Islam, 13(2).

L. Pass. Daniel. (2001). Dekontruksi Kebenaran; Kritik Tujuh Teori Agama. Yogyakarta: IRCiSoD.

Mircea, $\quad$ E. (2002). Sakral dan Profan. Yogyakarta : Fajar Pustaka Baru.

Priyanto, I.F. (2016). Memory, Cognition \& Disruptive Technology. Sesi V \& VI disampaikan pada Perkuliahan IsuIsu Kontemporer Informasi, MIP UGM Kamis, 8 September 2016 \& Kamis, 15 September 2016. Diposkan oleh Resti Laras Gilang Parindra

Riadi,H. (2014). Kesalehan Sosial Sebagai Parameter Kesalehan Keberislaman (Ikhtiar baru dalam menggagas mempraktekkan tauhid sosial). An Nida' Jurnal Pemikiran Islam,39(1).

Siahaan, H. M. (1986), Pengantar ke Arah Sejarah dan Teori Sosiologi. Jakarta: Erlangga

Wahab. A.J.(2015). Indeks Kesalehan Sosial Masyarakat Indonesia. Puslitbang Kehidupan Keagamaan Badan Litbang dan Diklat Kementerian Agama RI 